doi: 10.52370/TISC21350MP

\title{
THE IMPORTANCE OF RURAL AREAS IN THE CREATION OF TOURISM OFFERS DUE TO COVID-19 EXPANSION
}

\author{
Milan Počuča ${ }^{1}$; Jelena Matijašević ${ }^{2}$
}

\begin{abstract}
The Covid-19 virus pandemic has so far affected all aspects of human life and activity around the planet in an extremely invasive way. What has significantly attracted the attention of the general public is the impact of Covid-19 on the tourism sector, which, last year, suffered daily immeasurable losses. During the crisis caused by the Covid-19 pandemic, areas with relatively low population density came to the forefront in the domain of creating a tourism offer. In times of crisis, rural areas with open, unpolluted spaces, such as protected natural areas, become very attractive and sought after. Bearing in mind that, rural areas are those parts of the territory that has a relatively low population density, but may also have certain characteristics in terms of natural, geographical, and climate specifics, also in terms of the economy, etc. The research part of this paper will deal with the ratio of tourist arrivals and overnight stays, and indexes of tourist demand in 2020 in comparison to 2019, as well as the analysis of the frequency of visitation of tourist spots in Serbia.
\end{abstract}

Key Words: tourism, rural areas, Covid-19, The Republic of Serbia JEL classification: $Q 10, R 11, Z 30, Z 32$

\section{Introduction}

The pandemic caused by Covid-19 is of unprecedented proportions. The spread of the virus has an extremely invasive effect on all aspects of human life and activity around the world.

\footnotetext{
${ }^{1}$ Milan Počuča, PhD, Full Professor, Faculty of Law for Commerce and Judiciary in Novi Sad, Geri Karolja Street no. 1, Novi Sad 21000, The Republic of Serbia, +38163224740 , pocucabmilan@gmail.com

2 Jelena Matijašević, PhD, Associate Professor, Faculty of Law for Commerce and Judiciary in Novi Sad, Geri Karolja Street no. 1, Novi Sad 21000, The Republic of Serbia, +381616538747, jelena@pravni-fakultet.info
} 
The pandemic caused by the Covid-19 virus and all the measures taken in response to it, both in the world and in Serbia, have an extremely strong effect on many aspects of the daily life of the population. What has significantly attracted the attention of the general public, in addition to the impact on the health aspect and the socio-economic aspect in a broader sense, is the impact of Covid-19 on the tourism sector, which recorded daily immeasurable losses last year. According to a study by Rupasinghe et al. (2020), "Covid-19 has radically changed lives across the region and raised issues of funding, service delivery and governance that health system managers must answer" (p. 4).

The crisis caused by Covid-19 "has had severe consequences for the entire economy of the Western Balkans, as both supply and demand have declined simultaneously" (World Bank Group, 2020, p. 1). In this context, Praščević (2020) states that the announcement of the Covid-19 pandemic indicated a significant impact on economic events and trends, primarily through the possible emergence of an economic recession that would be global and different from the previous ones due to the unusual factor causing it."(p. 9). According to Tucaković (2020), "certain branches of the industry have been extremely hard hit and the question is how long it will take them to recover." This primarily refers to the aviation industry, tourism and service industry" (p. 2).

In theory, it is further stated that the pandemic "can certainly be considered a negative exogenous shock whose effects spread through the economic system, causing an economic downturn and recession. In the case of Covid19 , there is uncertainty regarding the duration and intensity of the shock" (Praščević, 2020, p. 9).

According to research by the World Travel and Tourism Council, it is estimated that the current pandemic will "cause the loss of about 100 million jobs in the tourism sector in the world, with about 3/4 of those jobs in G20 member states (comprised of 19 countries with the most developed economies in the world, and the EU as a separate member)" (Jovičić, 2020, p. 7). Furthermore, "it is estimated that the negative impacts of the pandemic on tourism will be manifested in the reduction of global gross domestic product by 2.7 trillion US dollars, which will mostly affect the economies of Asia, Europe, and North America, as key contributors of global tourist movements" (Jovičić, 2020, p. 8).

During the crisis caused by the Covid-19 pandemic, areas with relatively low population density came to the forefront in the domain of creating a 
tourist offer. In times of crisis, rural areas with open, unpolluted areas, protected natural areas, and mountains become very attractive and sought after. Rural areas are those parts of the territory of a state that has a relatively low population density, but may also have certain characteristics in terms of nature, geography and climate, economy, and culture, etc.

Therefore, in the conditions of the Covid-19 pandemic, rural areas are becoming primary in the field of creating a tourist offer in Serbia because, according to many experts, the emerging crisis has had a much lesser impact on this small segment of tourism than other sectors, which makes it a topic that deserves a more careful scientific review. Having in mind the topic of the paper, in the research part, the paper will deal with the ratio of tourist arrivals and overnight stays, and quarterly indexes of tourist overnight stays for the previous two years, as well as the analysis of the frequency of overnight stays in certain tourist spots in Serbia for the period between January and September of 2020.

\section{Significance of Rural Areas and Rural Tourism in the Conditions of Covid-19 Pandemic - Literature Review}

According to Počuča and Matijašević Obradović (2019), "tourism is one of the most complex economic and sociological phenomena of the modern world" (p. 554). It should be noted that "the biggest importance for the development of tourism is certainly the tourist destination/attraction" (Petrović et al., 2016, p. 62), whose popularization and intensity of visits are influenced by numerous factors. Certainly, the determining factor is "the attitude and opinion of tourists about the quality of the tourist destination. In this regard, tourist traffic is a significant indicator of the number of visits to a tourist destination" (Počuča \& Matijašević Obradović, 2020, p. 336).

However, the frequency of users of tourist services, and the occupancy of accommodation capacities are strongly influenced by the seasonality of the tourist economy, given that the highest percentage of active service is recorded during certain months. The seasonality of the tourism industry in connection with the potentially available stimulus that tourism as a commercial branch can achieve from the overall economic potential of the country significantly influences several other aspects. Thus, this combination of factors has a direct impact not only on the quantitative aspects of the tourist offer, in terms of the number and variety of tourist services, but also on the quality of offered tourist services, which again 
manifests itself in a gradual increase or decrease in interest of users of tourist services.

Thus, tourism has gradually become "recognized, not only as a consequence of economic development but also as a factor of economic development" (Stanić \& Vujić, 2016, p. 14).

Thanks primarily to the preserved natural resources and other aspects of a healthy environment, Serbia has significant advantages and numerous opportunities for the continuous development of tourism, especially in the field of rural tourism. As Cvijanović et al. (2017) state, significant potential for the development of tourism in Serbia concerns precisely rural areas (p. 872). The fact that tourism has a great influence on the development of rural areas is pointed out in Ćirić et al. (2014, p. 26). Therefore, the positive effects of tourism are numerous, not only locally but also globally. Tourism, with its primary concept, encompasses four important aspects of sustainable development: ecological, social, cultural, and commercial (Počuča et al., 2017).

Đorđević Milošević and Milovanović (2012) point out that rural tourism in Serbia is defined as tourism that offers the visitor a "rural environment" by enabling him to experience the synergy of life of nature, culture, and people in a unique way. "This implies that the visitor is offered an authentic, original experience and a return to the roots or essence of the rural way of life" (p. 47).

Analyzing the concept of rural development, it can be said that "comprehensive rural development includes demographic revival, use of available resources for healthy food production, development of nonagricultural activities, urbanization in terms of infrastructure development, education, culture, and environmental protection" (Veselinović \& Ignjatijević, 2013, p. 146). That being said, rural tourism is based on "principles of sustainability and implies a series of activities and services that the local population in rural areas organizes just based on the elements that characterize these rural areas. The offer in rural tourism includes not only tangible characteristics of nature, architecture, folklore, gastronomy but also more abstract ones such as, for example, traditional hospitality, customs, a culture of relations with nature, culture of communication, beliefs, and legends of local nationalities and religions that have influenced a specific way of life in a specific area"(Đorđević Milošević \& Milovanović, 2012, p. 47). 
According to Pejanović and Vujović (2008), "rural tourism is a form of tourism focused on essential issues, healthy nutrition of tourists and living in a healthy environment, through the integrated development of agriculture, with the respect towards aspects of sustainability" (p. 6). The main attractions of rural tourism are the experience of living and working in a rural household and authentic products, together with accompanying services (Lobo et al., 1999).

Table 1: SWOT analysis of rural development for the period 2014-2024 in the Republic of Serbia

\begin{tabular}{|c|c|}
\hline Strengths & Weaknesses \\
\hline \multicolumn{2}{|c|}{ Rural Development } \\
\hline $\begin{array}{l}\text { Diversity and attractiveness of the } \\
\text { rural environment; } \\
\text { Rich cultural heritage; } \\
\text { Preservation of traditional knowledge } \\
\text { and technologies; } \\
\text { Examples of good practice; } \\
\text { Started initiatives on the formation of } \\
\text { local social networks; } \\
\text { Adequate state of infrastructure in } \\
\text { some rural areas; }\end{array}$ & $\begin{array}{l}\text { Adverse demographic trends; } \\
\text { Lagging labor market; } \\
\text { Unfavorable social structure; } \\
\text { Inadequate diversification of income } \\
\text { on farms; } \\
\text { Insufficient use of cultural heritage; } \\
\text { Low infrastructure equipment; } \\
\text { Difficult access to social services; } \\
\text { Low level of social capital; }\end{array}$ \\
\hline Opportunities & Threats \\
\hline \multicolumn{2}{|c|}{ Rural Development } \\
\hline $\begin{array}{l}\text { Creation of new products and } \\
\text { services; } \\
\text { Public-private partnerships; } \\
\text { Resource revitalization; } \\
\text { Regional cross-border cooperation; } \\
\text { Use of the pre-accession period for } \\
\text { the growth of competitiveness, } \\
\text { application of standards with the use } \\
\text { of EU funds (IPARD); } \\
\text { Development of all types of tourism- } \\
\text { related to rural areas. }\end{array}$ & $\begin{array}{l}\text { Insufficient recognition of rural } \\
\text { uniqueness; } \\
\text { Low investor interest; } \\
\text { Rural poverty; } \\
\text { Insufficient recognition of the } \\
\text { uniqueness of small farms; } \\
\text { Stagnation in the EU integration } \\
\text { process; } \\
\text { Lack of state funding. }\end{array}$ \\
\hline
\end{tabular}

Source: Strategija poljoprivrede i ruralnog razvoja Republike Srbije za period 2014-2024 [Agriculture and Rural Development Strategy of the Republic of Serbia for the period 2014-2024], Službeni glasnik Republike Srbije, br. 85/14, p. 54-56

The Strategy of Agriculture and Rural Development of the Republic of Serbia for the period 2014-2024 (2014) contains a SWOT analysis which 
systematizes data about the advantages and possibilities of improving the situation, among others, in the field of rural development, but also about opportunities and threats in this area. In the following table, the mentioned SWOT analysis is presented. Following the emergence and pandemic expansion of the Covid-19 virus, the tourism sector and the concept of tourism offerings have suffered major losses and significant changes.

Dealing with the situation in the European Union, Praščević (2020) points out that, "The European Union as a leading tourist destination, with $40 \%$ of total international arrivals, is particularly affected. Some countries are especially endangered because they depend on tourism, and at the same time, they are significantly affected by the pandemic. Thus, the number of tourist reservations was reduced by $90 \%$ compared to the same period last year, it is estimated that as many as 6 million jobs were lost in the EU, with a large decline in tourism revenues: hotels recorded a decline of $85 \%$, tour operators $85 \%, 85 \%$ decline in train travel, $90 \%$ decline in the cruise line and air travel industry" (p. 16).

In the Republic of Serbia, the situation in the tourism sector has changed significantly after the appearance and expansive spread of the Covid-19 virus.

According to Luković and Stojković (2020), one of the more important changes is that "people will most likely avoid distant tourist destinations. The reason for choosing closer tourist destinations is reflected in the reduction of the risk of infection, but also in the reduction of the possibility of border closing (crossing many borders increases the risk for quarantine). Decisions made by tourists in favor of shorter routes can, among other things, significantly contribute to the more intensive development of domestic tourism" (p. 84).

To recall, the restrictive measures during, and immediately after the lifting of the state of emergency (March 15, 2020 - May 31, 2020), were reflected in the following (UNDP, 2020, p. 17):

1. "police curfew, including a ban on the movement of citizens on weekends and between 5:00 pm and 5:00 am on weekdays";

2. "complete restrictions on movement, including a travel ban for citizens over 65 (or over 70 for more rural, sparsely populated areas)";

3. "closure of all border crossings, including air, land and river border crossings, all of which were closed, except for transport crews and persons with special permits"; 
4. "airport closures, except for cargo and mail transport, search and rescue operations, humanitarian flights and emergency medical transport";

5. "closing of schools: kindergartens, schools and universities, all of which were completely closed";

6. "closure of public spaces: cafes, bars, restaurants, shopping malls and markets (or "farmers markets") were closed, except for pharmacies and supermarkets, as necessary";

7. "the closure of public transport, which was completely banned, except for food delivery and transport, which were still allowed as necessary".

In the conditions of the Covid-19 pandemic, rural areas are coming to the forefront in the field of creating a tourist offer in Serbia because, according to many experts, the new crisis has had a much smaller impact on this small segment of tourism than other sectors. As some studies point out, "during the crisis and in the post-crisis period, cities with a large number and density of inhabitants are much less in demand. Therefore, in Serbia, the offer should primarily focus on rural areas in open, unpolluted spaces, protected natural areas, mountains, and "remote" places (such as Pešter)" (Krasojević, 2020, p. 3).

On the other hand, intensifying the development of rural tourism creates numerous benefits for rural areas that can be revitalized in a certain, very concrete way, under the influence of more pronounced interest of tourists, greater investment in infrastructure and accommodation facilities, etc. In that sense, "Serbia as a country of rural character is one of the most agricultural countries in Europe. Rural development, as one of the areas of regional policy, is a key instrument for restructuring the agricultural sector whose task would be to allocate and strategically use the potential of attractive tourist villages" (Muhi, 2013, p. 131).

With this in mind, it is clear that rural areas that have become highly sought after and competitive in the tourism market in the context of the spread of the Covid-19 virus, have significantly higher opportunities to create a better and more comprehensive tourist offer to a large number of interested tourists and position themselves in the tourist market while providing quality tourist service to a large number of domestic tourists, who decided not to take risks with a tourist arrangement that would include crossing the state border and staying abroad.

In that sense, the importance of tourist offers in rural areas is emphasized, in conditions when the stay of our citizens abroad is almost impossible, or associated with high risks of transmitting the infection or limited movement 
in a certain time interval after returning to Serbia. Also, given the occupancy of accommodation in mountainous, rural, and spa areas in recent months, it is clear that quality and competitive tourist offer for predominantly rural areas (which until the outbreak of the pandemic were not nearly as attractive) can largely compensate for the preferences of domestic tourists in the desire to organize and spend their free time.

According to Ivanović (2020), "rural tourism suffers significantly fewer consequences due to the spread of Covid-19. Rural tourism is reserved for domestic guests everywhere in Europe, even in our country, so it depends less than other sectors on arrivals from abroad, which makes it more immune to the consequences of such negative events. Also, rural tourism is not burdened with numerous overhead costs such as employees, rents, loans, and interest rates, and therefore it can be stopped more easily, and also easier to start. There is little risk and it is easy to adapt to changes in demand, which makes it a segment of tourism that will survive more easily or will return more easily in such crisis periods" (p. 19).

\section{Methodology and Data Sources Used}

In order to specifically elaborate the topic of the paper, the research part of the paper will analyze the ratio of tourist arrivals and overnight stays on a monthly basis in the Republic of Serbia for the period between January and November of 2019 and between January and November of 2020, then, quarterly tourist overnight stays indicators for 2020 in relation to 2019, as well as the frequency of overnight stays in certain tourist places in Serbia for the period between January and September of 2020. The paper applies the analytical method in the theoretical analysis of content, the deductive method in drawing conclusions, and the basic quantitative analysis of data in the part dealing with the research. The research in this paper is based on the official data of the Republic Bureau of Statistics.

\section{Research Results and Discussion}

First, the concepts of tourist arrivals and overnight stays should be explained. Hence, "arrivals mean the number of tourists staying in the accommodation facility, and overnight stays include the number of overnight stays realized by tourists in the accommodation facility during the calendar year" (Lekić \& Perunović Ćulić, 2019, p. 157). 
The following table will present the ratio of arrivals and overnight stays of tourists on a monthly basis in the Republic of Serbia for the period between January and November of 2019 and January and November of 2020. The stated period was taken into account in this research because the last available data for 2020 by the Republic Bureau of Statistics, in this domain, was published in November.

Table 2: Tourist arrivals and overnight stays on a monthly basis in the Republic of Serbia for the period between January and November of 2019 and January and November of 2020.

*(in thousands)

\begin{tabular}{|c|c|c|c|c|}
\hline & \multicolumn{4}{|c|}{ Republic of Serbia } \\
\hline & \multicolumn{2}{|c|}{ Arrivals } & \multicolumn{2}{|c|}{ Overnight stays } \\
\hline & Total & Domestic & Total & Domestic \\
\hline \multicolumn{5}{|l|}{2019} \\
\hline I & 177.7 & 94.8 & 551.2 & 320.8 \\
\hline II & 195.9 & 115.4 & 607.7 & 409 \\
\hline III & 233.3 & 121.3 & 634.8 & 377.5 \\
\hline IV & 300.9 & 169.7 & 776.5 & 491.5 \\
\hline $\mathrm{V}$ & 384.8 & 220.8 & 980.1 & 643.3 \\
\hline VI & 358.5 & 174.4 & 988.6 & 606.4 \\
\hline VII & 391.4 & 175.5 & 1150 & 692.3 \\
\hline VIII & 448.3 & 210.5 & 1302.8 & 812.5 \\
\hline IX & 344 & 148.9 & 906 & 508.1 \\
\hline $\mathrm{X}$ & 332 & 157.6 & 8456 & 473.8 \\
\hline XI & 253.5 & 124.0 & 644.1 & 356.1 \\
\hline \multicolumn{5}{|l|}{2020} \\
\hline $\mathrm{I}$ & 220.7 & 114 & 689.6 & 393 \\
\hline II & 233 & 141.6 & 729.7 & 494 \\
\hline III & 102.6 & 64.3 & 344,6 & 237.2 \\
\hline IV & 6.3 & 5.2 & 41.7 & 29.7 \\
\hline V & 47.7 & 44.1 & 170.7 & 151.9 \\
\hline VI & 170.4 & 146 & 560.2 & 501.9 \\
\hline VII & 193.9 & 169.6 & 737.4 & 670.2 \\
\hline VIII & 294.3 & 263.7 & 1080.7 & 1000.5 \\
\hline IX & 195.6 & 162.2 & 698.2 & 603.9 \\
\hline $\mathrm{X}$ & 168.5 & 124.9 & 528.8 & 403.2 \\
\hline XI & 98.2 & 71.4 & 345.2 & 253.2 \\
\hline
\end{tabular}

Source: Šutić, V. (Ed). (2021). Monthly Statistical Bulletin 11/2020, Statistical Office of the Republic of Serbia, Belgrade, p. 59; Šutić, V. (Ed.) (2020). Monthly Statistical Bulletin 01/2020, Statistical Office of the Republic of Serbia, Belgrade, p. 59 
The following table (Table 3) will present the quarterly indexes of tourist nights in the Republic of Serbia for 2020, as well as for 2019, while Table 4 will express numerical and percentage data on the frequency of overnight stays in individual tourist destinations in Serbia, for the period between January and September of 2020.

Table 2: Quarterly index of tourist overnight stays in the Republic of Serbia for 2019 and 2020 (\%)

\begin{tabular}{|l|l|l|l|l|l|l|l|}
\hline & \multicolumn{4}{|c|}{$\begin{array}{c}\text { Quarterly index of tourist } \\
\text { overnight stays for 2019 }\end{array}$} & \multicolumn{3}{c|}{$\begin{array}{c}\text { Quarterly index of } \\
\text { tourist overnight stays } \\
\text { for 2020 }\end{array}$} \\
\cline { 2 - 8 } & $\mathrm{Q} 1$ & $\mathrm{Q} 2$ & $\mathrm{Q} 3$ & $\mathrm{Q} 4$ & $\mathrm{Q} 1$ & $\mathrm{Q} 2$ & $\mathrm{Q} 3$ \\
\hline Toatal & 103.9 & 107.2 & 105.6 & 116.6 & 98.3 & 28.1 & 74.9 \\
\hline $\begin{array}{l}\text { Domestic } \\
\text { tourists }\end{array}$ & 101.3 & 107.6 & 105.4 & 113.6 & 101.5 & 39.3 & 113 \\
\hline $\begin{array}{l}\text { Foreign } \\
\text { tourists }\end{array}$ & 108.3 & 106.4 & 105.8 & 120.6 & 93.2 & 8.9 & 17.9 \\
\hline
\end{tabular}

Source: Stančić, K. (Ed.) (2020). Trends - III quarter of 2020, Statistical Office of the Republic of Serbia, Belgrade, p. 51

Table 3: Frequency of overnight stays in certain tourist destinations in Serbia, for the period between January and September of 2020

\begin{tabular}{|l|l|l|l|l|l|l|l|}
\hline \multicolumn{7}{|c|}{ Tourist destinations in the Republic of Serbia } \\
\hline Spa centers & \multicolumn{2}{|l|}{$\begin{array}{l}\text { Mountain } \\
\text { regions }\end{array}$} & \multicolumn{2}{|l|}{$\begin{array}{l}\text { Other tourist } \\
\text { destinations }\end{array}$} & $\begin{array}{l}\text { Other destinations and } \\
\text { cities-Belgrade and Novi } \\
\text { Sad }\end{array}$ \\
\hline Num. & $\%$ & Num. & $\%$ & Num. & $\%$ & Num. & $\%$ \\
\hline $\begin{array}{l}1.8 \\
\text { mil. }\end{array}$ & 36.4 & $\begin{array}{l}1.528 \\
\text { mil. }\end{array}$ & 30,9 & $\begin{array}{l}807 \\
\text { thousand }\end{array}$ & 16.3 & $\begin{array}{l}811 \\
\text { thousand }\end{array}$ & 16.4 \\
\hline
\end{tabular}

Source: Stanciić, K. (Ed.) (2020). Trends - III quarter of 2020, Statistical Office of the Republic of Serbia, Belgrade, p. 52

Until 2019, tourist activity in Serbia was recording a stable increase. However, this positive trend did not continue in 2020, when, due to a pandemic caused by the Covid-19, there was a decline in tourism.

If the data from Table 1 is analyzed in more detail, can be seen the monthly continuity in the number of tourist arrivals and overnight stays in Serbia during 2019. 
However, from April and May 2020, there are major changes not only in the number of tourists who came and/or spent the night in Serbia, but also in the structure of tourists whose arrivals were officially recorded and statistically analyzed. From April 2020, the number of domestic tourists is much higher in the total values of arrivals and overnight stays, than before.

So, as a consequence of the spread of the Covid-19 virus, it can be noticed two trends, in the first place, a significant decrease in the number of tourists who visited our country and decided to spend the night, and in the second place, a change in the structure of tourists who chose tourist places in Serbia. In other words, in the structure of tourists who came and/or spent the night in Serbia, the focus has shifted to domestic tourists, who, for the reasons already mentioned, still prefer domestic tourist destinations.

If the quarterly indexes of tourist overnights stays in the Republic of Serbia for 2019 and 2020 are considered, it can be seen that the indexes of overnight stays of domestic and foreign tourists in the second and third quarters of 2020 recorded extremely low values, having in mind the same quarterly periods in the previous year. If, for example, is considered the second quarter of the index of tourist overnight stays in both years, it can be seen that in 2019 it amounted to 106.4, while in 2020 it amounted to 8.9.

As noted in the official report, "after extremely poor results in the second quarter of 2020, when the number of overnight stays of foreign tourists compared to the same period in 2019 dropped by $91.1 \%$, in the third quarter the number of overnight stays of foreign tourists was somewhat higher $(241,565)$, which is $82.1 \%$ less than in the same period in 2019" (Stančić, 2020, p. 51).

If the data from Table 3 are analyzed, it can be noticed that the largest number of tourists opted for spa and mountain destinations in the period between January and September of 2020. Expressed by the number of tourist overnight stays, the most frequently visited tourist places in the period between January and September of 2020 were spa centers, with about 1.8 million overnight stays, which represents $36.4 \%$ of the total number of tourist overnight stays in the Republic of Serbia.

According to official data, "out of that number, 1,2 million overnight stays were realized in Vrnjačka Banja and Sokobanja. The visitors of the spa centers were mostly domestic tourists (95\%)" (Stančić, 2020, p. 52). 
According to the frequency of visits to tourist destinations, mountain regions and other tourist destinations follow, with about 1.528 (mil.) or 807 thousand overnight stays. According to official data, "in mountainous regions, the majority of visitors are domestic tourists $(87,4 \%$ of the total number of overnight stays). The most visited mountains were Zlatibor (about 478 thousand overnight stays) and Kopaonik (about 394 thousand overnight stays)" (Stančić, 2020, p. 52).

\section{Conclusion}

Tourism in the world, and even in Serbia, has been recording almost continuous growth in the past few decades (except for occasional crises at the global level), which has shown this sector's strength, resilience, and adaptability.

The Covid-19 virus pandemic is the biggest challenge the world has faced since World War II. Tourism needs open borders, and stable political and socio-economic climate, and, above all, safe health and security conditions. The collapse of such stability at the global level at the beginning of March last year led, de facto, to the complete disappearance of tourist movements and tourist business (Jovičić, 2020, p. 6).

In order to analyze the demand for tourist offers and a comparative overview of the degree of their utilization for the previous two years, but also the position in which rural tourism as a branch of tourism has reached the opportunity to significantly develop in the new conditions of tourist functioning the paper analyzes tourist arrivals and overnight stays on a monthly basis for the previous two years, then, quarterly tourist overnight stays indexes for 2019 and 2020, as well as the frequency of overnight stays in certain tourist destinations in Serbia for the period between January and September of 2020.

In conclusion, after analyzing the available statistics, it can be said that as a consequence of the spread of the Covid-19 virus, there is, in the first place, a significant reduction in the number of tourists who visited our country and decided to spend the night and secondly the structural change of tourists who have decided to travel in/to Serbia.

Primarily, from April 2020, the number of domestic tourists is much higher in the total values of arrivals and overnight stays, than was the case before. 
Furthermore, the most frequently visited tourist destinations in the period between January and September of 2020 were spa resorts and mountain regions, with about $67,3 \%$ of the total number of tourist overnight stays in the Republic of Serbia for the entire observed period.

\section{References}

1. Cvijanović, D., Matijašević-Obradović, J., Škorić, S. (2017). The Impact of Air Quality conditioned by emission of poluttants to the Development of Rural Tourism and potentials of Rural Areas. Economics of Agriculture, Vol. 64, No. 3, 871-886.

2. Ćirić, M., Počuča, M., Raičević, V. (2014). Level of customer orientation and customer protection in hotels in Serbia. Economics of Agriculture, Vol. 61, No. 1, 25-39.

3. Đorđević Milošević S., Milovanović J. (2012). Održivi turizam u funkciji ruralnog razvoja - Mala poljoprivredna gazdinstva i ruralni turizam $u$ Srbiji [= Sustainable tourism in the function of rural development - Small farms and rural tourism in Serbia], Fakultet za primenjenu ekologiju Futura, Univerzitet Singidunum, Beograd \& Agroznanje, Vršac \& FAO, Budimpešta.

4. Ivanović, V. (2020). Ruralni turizam u doba Korone [= Rural tourism in the Covid-19 era]. Turistička solidarnost, vanredno izdanje, 19.

5. Jovičić, D. (2020). Osvrt na uticaj pandemije virusa Covid-19 na turizam [= A review of the impact of the Covid-19 virus pandemic on tourism]. Turistička solidarnost, vanredno izdanje, 6-12.

6. Krasojević, B. (2020). Preporuke Svetske turističke organizacije za oporavak turizma [=Recommendations of the World Tourism Organization for tourism recovery]. Turistička solidarnost, vanredno izdanje, 3-5.

7. Lekić, D., Perunović Ćulić, T. (2019). Izveštaj o stanju životne sredine u Republici Srbiji za 2018. godinu [Report on the state of the environment in the Republic of Serbia for 2018], Ministarstvo zaštite životne sredine Agencija za zaštitu Životne sredine, Beograd.

8. Lobo E. R., Goldman E. G., Jolly A. D., Wallace B. D., Schrader L. W., Parker A. S. (1999). Agricultural Tourism: Agritourism benefits 
agriculture in San Diego County, California Agriculture, University of California, California, USA.

9. Luković, S., Stojković, D. (2020). Covid-19 pandemic and global tourism. Hotel and Tourism Management, Vol. 8, No. 2, 79-88.

10. Muhi, B. (2013). Ruralni turizam kao komponenta integralnog i održivog razvoja sela $\mathrm{u}$ Vojvodini [= Rural tourism as a component of integral and sustainable rural development in Vojvodina]. Zbornik Matice srpske za društvene nauke, No. 142, 129-137.

11. Pejanović R., Vujović S. (2008). Ruralni razvoj i agroturizam [= Rural development and agritourism]. Agroekonomika, Vol. 37-38, No. 37-38, 5 15.

12. Petrović, G., Karabašević, D., Maksimović, M. (2016). Promet turista i prihodi od turizma u Republici Srbiji [=Tourist turnover and income from tourism in the Republic of Serbia]. Ekonomski signali, Vol. 11, No. 2, 61 75.

13. Počuča, M., Matijašević-Obradović, J., Drašković, B. (2017). Correlation between the Air Quality Index SAQI_11 and Sustainable Rural Development in the Republic of Serbia. Economics of Agriculture, Vol. 64, No. 3, 1249-1262.

14. Počuča, M., Matijašević Obradović, J. (2020). Environmental impacts of Tourist Traffic in Mountain Resorts in the Republic of Serbia. The Fifth International Scientific Conference (Thematic Proceedings) "Tourism in Function of Development of the Republic of Serbia - Tourism and Rural Development", 2, University of Kragujevac, Faculty of Hotel Management and Tourism in Vrnjačka Banja, 335-350.

15. Počuča, M., Matijašević Obradović, J. (2019). Impact of Tourism on the Quality of the Environment in the field of Protected Areas. The Fourth International Scientific Conference (Thematic Proceedings) "Tourism in Function of Development of the Republic of Serbia - Tourism as a Generator of Employment", 2, University of Kragujevac, Faculty of Hotel Management and Tourism in Vrnjačka Banja, 553-569.

16. Praščević, A. (2020). Ekonomski šok pandemije Covid-19 prekretnica u globalnim ekonomskim kretanjima [= Economic shock of the 
Covid-19 pandemic - a turning point in global economic developments]. Ekonomske ideje i prakse, No. 37, 7-22.

17. Rupasinghe, N., Secci, F., Đukić, P., Smith, O., Forde, I., Aliu, M., Rigolini, J. (2020). Uticaj Covid-19 na zdravstvene sisteme na Zapadnom Balkanu [= Impact of Covid-19 on health systems in the Western Balkans], http://pubdocs.worldbank.org/en/726641590707354436/RER17-Healthnote-SRB.pdf, (February 10, 2021).

18. Stanić, M., Vujić, T. (2016). Turizam kao faktor ekonomskog razvoja [=Tourism as a factor of economic development]. Međunarodni naučni skup - Sinergija 2016"Uloga i značaj turizma u privrednom rastu i razvoju Republike Srpske i BiH", Bijeljina, Vol. 17, 14-19.

19. Stančić, K. (Ed.) (2020). Trends - III quarter of 2020, Statistical Office of the Republic of Serbia, Belgrade.

20. Strategija poljoprivrede i ruralnog razvoja Republike Srbije za period 2014-2024 [= Agriculture and Rural Development Strategy of the Republic of Serbia for the period 2014-2024], Službeni glasnik Republike Srbije, br. $85 / 14$.

21. Šutić, V. (Ed.) (2021). Monthly statistical Bulletin 11/2020, Statistical Office of the Republic of Serbia, Belgrade.

22. Šutić, V. (Ed.) (2020). Monthly statistical Bulletin 01/2020, Statistical Office of the Republic of Serbia, Belgrade.

23. Tucaković, M. (2020). Covid - 19 implikacije i kuda dalje? [= Covid 19 implications and where to go next?]. Stanton Chase Newswire, No. 21, 2.

24. UNDP (2020). Covid-19 - Procena socio-ekonomskog uticaja [= Covid-19 - Socio-economic impact assessment], file:///C:/Users/Jelena/ Downloads/seia_report-sr\%20(1).pdf (January 10, 2021).

25. Veselinović J., Ignjatijević, S. (2013). Pravni okvir i ekonomske mere za unapređenje agroturizma [= Legal framework and economic measures for the promotion of agritourism], Međunarodni naučni skupPlanska $i$ normativna zaštita prostora i životne sredine, Palić, 145-150. 
26. World Bank Group (2020). Ekonomski i socijalni uticaj Covid-19, Ekonomski izveštaj za Zapadni Balkan, Br. 17 [= Economic and Social Impact of Covid-19, Economic Report for the Western Balkans, No - 17], http://pubdocs.worldbank.org/en/921021588146363088/WB-RER17-TheEconomic-and-Social-Impact-of-COVID-19-Setting-the-Stage-

Bosnian.pdf, (January 28, 2021). 